\title{
IMPACT OF DIGITALIZATION OF BANKS
}

\author{
${ }^{1}$ Mr.Naveen Chinni \\ Assistant Professor \\ Department of Management Studies \\ Gayatri Vidya Parishad College for Degree and \\ PG Courses (A) \\ Visakhapatnam,
}

\author{
${ }^{2}$ Dr.P.V. Mohini \\ Associate Professor \\ Department of Management Studies \\ Gayatri Vidya Parishad College for Degree and \\ PG Courses (A) \\ Visakhapatnam,
}

\author{
${ }^{3}$ Mr.S.Srinadh \\ II MBA Student \\ Department of Management Studies \\ Gayatri Vidya Parishad College for Degree and PG Courses (A) \\ Visakhapatnam,
}

Article DOI: https://doi.org/10.36713/epra6556

\begin{abstract}
Years ago, when people talked about the work of a bank, they would come up with answers such as accepting deposits and providing loans, but today the scenario has changed, nowadays it's more like bankinganytime, banking anywhere. This requires an innovative, robust, secure, optimized and agile platform to meet the expectations of empowered and tech-savvy customers. This is due to digitalization of banks. Change of data into a digital database with appropriate use of technology is called as digitalization. The concept of digitalization is not a mere transformation from traditional methods of banking towards a digital method. It is a crucial change how banks and other financial institutions learn about, interact and satisfy customers. Banks are the backbone of any economy. Banking sector is the largest and vital player in financial sector, it plays a dominant role in the development of the individual as well as the nation. IT (information technology) has given a push new innovations and methods in the product development and their delivery in the banking and finance sector. The focus of banking is shifting from mass banking to class banking. The start of value added and customized products and services leads them to technology enable banking. The main objective of this paper is to understand the impact as well as the pros and cons of digitalization.
\end{abstract}

KEY WORDS: Digitalization, Innovative, Banking sector, Information technology, Customized products

\section{INTRODUCTION}

Financial sector plays a prominent role in growth of a country's economy. Banking is an important medium in today's financial activities and digital banking is becoming more popular and more advanced. One of the trends in the banking industry is large banks investing more and more in $\mathrm{R} \& \mathrm{D}$ and into the future. The modern world is filled with digitalization, banking sector is not exception to it. Digitalization has become integral part of our life, without which we feel the world is nothing. Banks of all sized are making huge investments in digital initiatives in order to maintain a unique nature and deliver the maximum need of a customer. Digitalization leads to more customisation and closer to customer. When a bank renders its services through online and 
customer can make transactions, other activities online, it is called digital banking. In order to improve the customer service, Reserve Bank of India in 1988 set up a committee on computerization in banks headed by Dr. C. Rangarajan. The first bank in India to offer

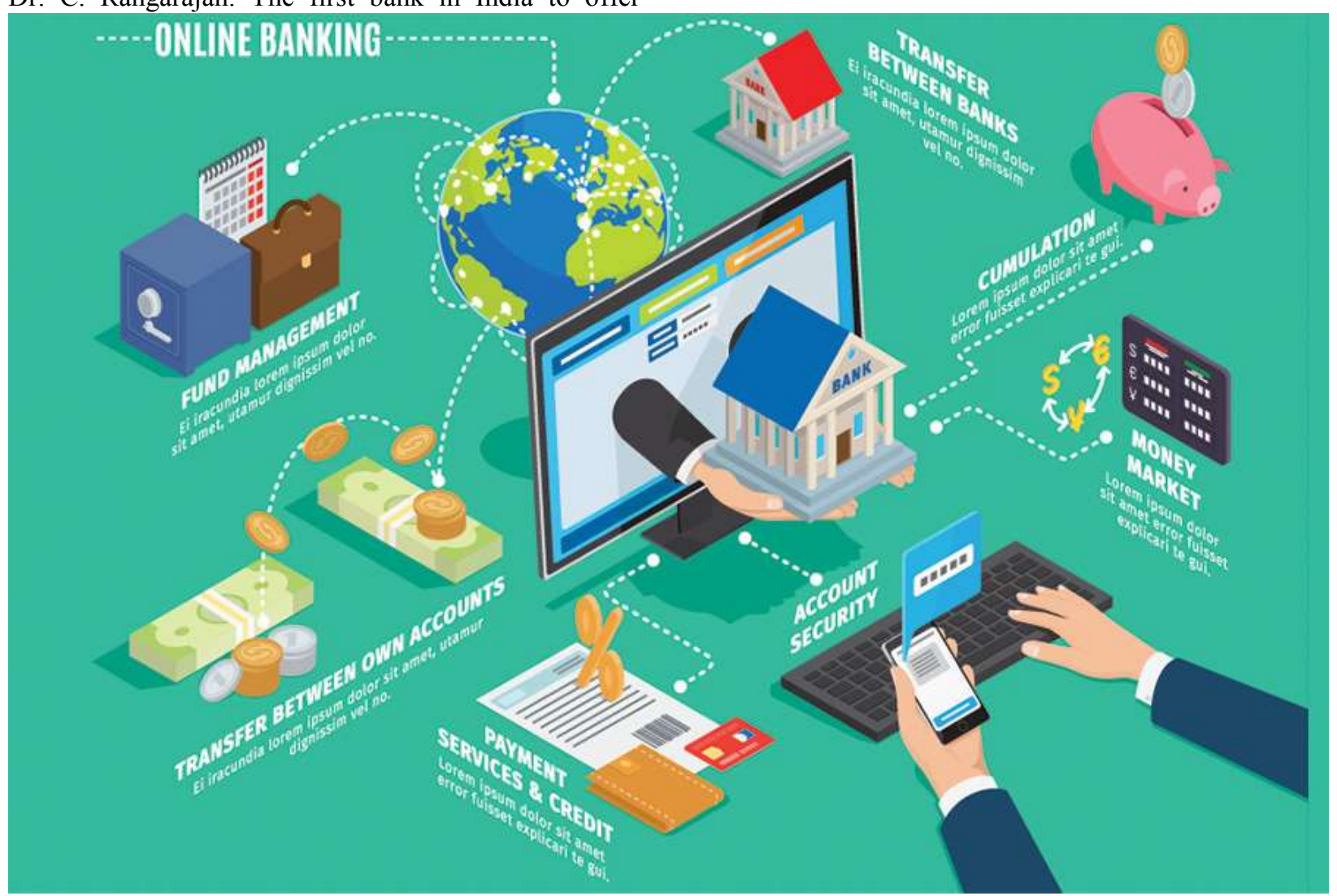

Digital revolution in the Indian banking sector

(www.forbesindia.com)

\section{OBJECTIVES}

- To understand the pros and cons of digitalization.

- To understand the impact of digitalization of banks in India.

- To know the future of banking technology in India.

\section{METHODOLOGY}

This study is done by studying and referring theoretical data available from various online resources. This is purely theoretical paper.

\section{PROS OF DIGITALIZATION}

- Customer service: With the internet freely available everywhere, the customer needs to connect and can access his account. It saves time and expense as he no longer travels to the bank. One can sit back relax and make works banks used technology-based solution to raise the revenues, increase customer experience and reduce cost structure. internet banking was the ICICI bank in 1996. Indian 
calculations and record keeping reduced. With the records made electronical, it is possible to generate reports and compare whenever possible.

- Reduction of fake currency: With the use of digital banking and digital currency, most of the fake currency has reduced due to less usage of physical notes.

- Gap between Rural and Urban: Before digitalization only urban areas has all services, but not rural areas. From digitalization both rural and urban gets services from wherever they want. This the gap between rural and urban has reduced.

- Increase of customers: The encouragement of government to use electronic wallets made a rapid growth in the usage of technology in financial services. Nation can expect a greater number of people using debit/credit cards in the coming years.

- Chatbots: Many banks are already using AI based chatbots in their customer care services. People will see more updated chatbots with speed in their response, quality of interaction and quality of services rendered.

- Mixed digital and physical processes: Banks today offer merge digital and physical process to their customers. The customers could walk to bank and do their transactions by using their devices. This would certainly increase, especially in rural areas.

\section{CONS OF DIGITALIZATION}

- Security threats: External risks such as hacking, sniffing expose banks to security risks. Not only external, banks also have internal risks such as employee fraud or employee with collision with customers.

- Customer awareness: Though banks are updated but most of the customers are not, they don't know the use of e-services. This also may lead to fraud by external people. This is the major drawback in India.

- Fear factor:The biggest barriers of digital banking is fear of losing money. People from rural areas or older people use only conventional methods due to this reason. They fear of e-services.

- Training: Lack of sufficient knowledge and skills is a major backdrop for workforces to deal with pioneering and updating technologies. Training for all the employees whenever there is a change in IT is required.

\section{IMPACT OF DIGITALIZATION OF BANKS}

Digitalization in the country brings innovation, job opportunities and growth in the economy. Due to this adoption the banking sector in the country face a remarkable change. It is not possible to avoid the growth and services rendered by banks. By looking at the present scenario customers are taking more and more advantage of digitalization. With this bank have become more customer centric. Following are the devices and methods which changed the phase of Indian banking system.

- ATM's (Automatic teller machines)

- Telebanking

- Electronic Compensation Services (ECS)

- Electronic funds transfer (EFT)

- Real time gross settlement (RTGS)

- Point of sale terminal

In this crucial innovative business model, there is a key challenge where customers are protected against cybercrime. The change of digitalization and the continuity of it should try to reduce the costs for the industry, since it will reduce labour and automate the system.

\section{FUTURE OF BANKING TECHNOLOGY IN INDIA}

- Machine learning: Customers' needs can be predicted and provide them more customised which suits them through Data science. Some of the private banks have already adopted the technology and working on it for more efficiency.

- Artificial Intelligence: With artificial intelligence making a place in digital banking India, brings major changes in the banking process. In the future banking AI brings the power of innovative data analytics to challenge fraudulent activities, it also accomplishes anti-money laundering activities within seconds, which normally take hours or days.

- Personalized service: Digitalization of banks help customers, to customize their screens based on their past usage data. It will also help in filling certain details of the customer automatically in online forms. This will ensure well user practice.

- Safekeeping: With passwords and OTPs already in usage, customers now able to use biometric authentication, face recognition and voice recognition. ATMs will be screenless and can be controlled by smart devices. 
- $\quad$ Blockchain 2.0 technology: More and more the usage of blockchain technology that means the account details of a customer will be upheld in real time across banks, neutralizing the risk of frauds by criminals.It offers a highsecurity, low-cost way of sending payments that cuts down on the need for verification from third parties and beats processing times for traditional bank transfers.

\section{CONCLUSION}

Technologically India is a very escalating country. Our country not only adopt technology but are constantly innovating,we are at the cutting edge of technology. Therefore, Indian digital banking future is bright and nation can expect new innovations and services from the banking sector. Artificial intelligence (AI) and Business Analytics has power to bring a key change. AI powered Robots is projected to be the future game changer in the banking sector. Several private banks are preparing to replace Robots for customer service, credit approval process and investment advisory to improve the customer service and cost feasible in the long run. The most preferred banking in the future is digital baking.

\section{REFERENCES}

1. Ryan North, professional Blogger, Entrepreneur and Bankerhttps://www.enterpriseedges.com/roleof-digital-banking-india

2. Prof. Bijoy Bhattacharyya, Dean Banking \& Ms. Swati Pradhan, Deputy Manager - Research,S. P. Mandali's Prin. L. N. Welingkar Institute of Management Development and Research (WeSchool), http://www.forbesindia.com/article/weschool/digita l-revolution-in-the-indian-banking-sector/47811/1

3. Esha Handa, in Journal of Advances and Scholarly Researches in Allied Education | Multidisciplinary Academic Research http://www.ignited.in/I/a/89440

4. Frank Hamilton, Latest Trends In Digital Banking: A Must Read For New-Age Customershttps://www.paymentsjournal.com/latesttrends-in-digital-banking-a-must-read-for-new-agecustomers/

5. Mrs. Bhagyashree N. Deshpande, Assistant professor, management department (commerce), Tilak Maharashtra Vidyapeeth, Pune, Maharashtra, India.

6. DQIndia Online, Top 5 trends for digital payments in 2020, https://www.dqindia.com/top-5-trendsdigital-payments-2020/

7. Dr. Mrs. Manisha Vikas Jagtap, The Impact of Digitalisation on Indian Banking Sector, https://doi.org/10.31142/ijtsrd18688 